\title{
Differentiation of environmental aquatic bacterial isolates by MALDI-TOF MS
}

Natalija Topić Popović ${ }^{1}$, Snježana P. Kazazić*², Ivančica Strunjak-Perović ${ }^{1}$, Rozelindra ČožRakovac $^{1}$

${ }^{1}$ Laboratory for Aquaculture Biotechnology, Division of Materials Chemistry, Rudjer Bošković Institute, Bijenička cesta 54, 10002 Zagreb, Croatia

${ }^{2}$ Laboratory for Mass Spectrometry, Division of Physical Chemistry, Rudjer Bošković Institute, Bijenička cesta 54, 10002 Zagreb, Croatia

*Corresponding author:

Dr. Snježana Kazazić

Division of Physical Chemistry

Rudjer Bošković Institute

Bijenička cesta 54

HR-10002 Zagreb

Croatia

e-mail: snjezana.kazazic@irb.hr

Tel: +385-1-4680 096

Fax: +385-1-4680 245 


\begin{abstract}
Identification of bacteria in aquatic and environmental applications, for monitoring purposes and research, for health assessments and therapy considerations of farmed and free-living aquatic organisms, still relies on conventional phenotypic and biochemical protocols. Although molecular techniques based on DNA amplification and sequencing are finding ways into diagnostic laboratories, they are time-consuming, costly and difficult in the case of multiplex assays. Matrix-assisted laser desorption/ionization time of flight mass spectrometry (MALDITOF MS) is a rapid and accurate proteomic method reliable for identification of unknown bacteria to the genus and species level. Upon extension of databases, it will certainly find its position in environmental sciences. The paper presents an overview of the principle of the method, its effectiveness in comparison with conventional and molecular identification procedures, and applicability on environmental and aquatic isolates, discussing its advantages and shortcomings, as well as possible future implementations.
\end{abstract}

\title{
Keywords:
}

MALDI-TOF MS, environmental bacteria, fish, crayfish 


\section{Funding source}

This work was supported by the Ministry of Science, Education and Sports of the Republic Croatia [grant numbers 098-1782739-2749, 098-0982915-2945]. 


\section{Introduction}

The broad microbial biodiversity in aquatic environments fluctuates in respect to environmental conditions, differing from one aquatic macroenvironment to another, as well as in various sublocations in the same aquatic macroenvironment. Microorganisms are integral components of all aquatic ecosystems, and they are essentially responsible for biogeochemical cycles and key environmental processes (Amalfitano et al., 2014). In association with organisms living in waters, they exist mostly as symbionts and sometimes as pathogens. Therefore, fish, crayfish and other aquatic organisms are susceptible to a variety of bacterial infections, some of them host specific, some general, and some associated with immunosuppressive impact of water pollution (Austin and Austin, 1999). They can be either pathogenic to wild and cultured species or pose a threat for outbreaks of diseases under favorable conditions. Some bacterial fish pathogens may also infect humans and cause zoonotic diseases, mostly in immunocompromised patients. Consequently, it is apparent that the attention has to be devoted to rapid and accurate identification of environmental bacterial isolates.

Most methods for bacterial cultivation and identification are still based on the application of general and/or specific culture media, standard morphological, physiological and biochemical tests and their comparison to standard results. Routine steps for culture and identification of an organism, from sample collection and preparation to the interpretation of biochemical results from appropriate identification tables, usually take up to five days, or 96 hours (Buller, 2004). However, prompt and accurate identification is essential in order to be able to successfully cope with disease-causing environmental bacteria. Along with characterization based on phenotypic properties of bacteria, a number of nucleic acid methods have been developed. They alone do not define the bacterium and must be considered together with the phenotypic ones, but are very helpful in better definition of the bacterium. These methods mainly comprise the $\mathrm{G}+\mathrm{C}$ ratio, DNA-DNA hybridization, ribotyping and fluorescent in situ hybridization (Okafor, 2011). The real-time PCR and 16S ribosomal RNA (16S rRNA) sequencing enabled microbiologists to obtain information on bacterial composition without cultivation. Though time-consuming, costly and difficult in the case of multiplex assays, PCR is now a common technique used in medical and biological research (Campos Braga et al., 2013).

However, there are several challenges in identification of environmental, and particularly aquatic bacteria, such as discrimination between closely related environmental strains, need for rapid identification in some disease outbreaks, identification of rare or less frequent microorganisms which are difficult to discriminate with classical techniques. All of these challenges can be successfully tackled with the application of matrix-assisted laser desorption/ionization time of flight mass spectrometry (MALDI-TOF MS). The principle and advantages of the method will be discussed in this review, as well as the recent breakthroughs, with particular emphasis on its ability to differentiate environmental bacterial isolates.

\section{MALDI-TOF MS, the method}

The mass spectrometry (MS) for microbial biotyping was initially attempted by analysis of lipid content profiles for some bacterial species (Anhalt and Fenselau, 1975). Other MS methods such as pyrolysis MS (lipid biomarker), fast atom bombardment MS (lipid biomarker), gaschromatography MS (carbohydrate biomarker) and electrospray ionization MS (protein/peptide 
biomarker) were also employed with moderate success (Mazzeo et al., 2006). In the 1980s, the development of soft ionization matrix-assisted laser desorption/ionization mass spectrometry allowed the analysis of relatively larger protein biomarkers (Karas et al., 1985). MALDI-TOF MS for direct recognition of bacterial proteins in whole colonies was introduced in the nineties (Claydon et al., 1996; Holland et al., 1996; Lavigne et al., 2013). Whole or intact bacteria comprise cells suspended in a solution and/or deposited directly on the sample holder, as exposure to solvents, acids or water in the MALDI matrix tends to lyse them (Fenselau and Demirev, 2001). Protein profiles can be obtained from a single bacterial colony directly deposited on the target plate and overlaid with the matrix solution (Seng et al., 2010). According to Emami et al. (2012), the quality of spectra obtained using lysates was higher than those form intact whole cells, with the advantage that the instrument and supplies would not be contaminated if using microbiologically sterile lysates.

The method detects mainly the most abundant and conserved ribosomal protein fractions of bacteria which can be used for classification of the organisms (Lay, 2001). The bacterial identification is based on the detection of mass signals from proteins that are specific at genus, species or sub-group levels (Benagli et al., 2012). Measured mass signals are compared with mass spectra for referent bacterial strain collected in dedicated mass spectra library (library based approach) or with publicly available proteomics/genomics data (bioinformatics enabled approach) (Sandrin et al., 2013). Bioinformatics enabled biotyping usually require accurate peptide mass measurement and mass spectrometers for these experiments are equipped with a mirror which reflects ions using an electric field, thereby doubling the ion flight path and increasing the resolution and mass measurement accuracy. Time of flight of the ions in gas phase is relative to a mass/charge ratio $(\mathrm{m} / \mathrm{z})$, and ions with a high $\mathrm{m} / \mathrm{z}$ value fly slower then ions with a low $\mathrm{m} / \mathrm{z}$ value. Due to the possibility to ionize and introduce non-volatile molecules into the mass spectrometer, the method enables classification and identification of microorganisms (Risch et al., 2010). The mass spectra are thus considered specific fingerprints or molecular profiles of bacteria analyzed, and are compared with the spectra in databases developed by various bioinformatic tools (Mazzeo et al., 2006). Different search engines were developed in order to build and search databases of bacterial protein spectra (Bright et al., 2002), as well as fingerprint libraries for mass spectral peaks, typically in the range of 4-15 kDa, with a key requirement of spectral reproducibility (Demirev et al., 1999). Protein databases for bioinformatics enabled approach are based on Swiss-Prot/TrEMBL or NCBInr data and have a low number of protein entries for bacteria of partially sequenced genomes, such as various environmental bacteria (Mazzeo et al., 2006). For commercial biotyper platforms mass spectrometers are supplied with database systems for routine identification of bacteria, with spectra collected from reference strains, containing up to 2000 species with over 3000 spectra (Lavigne et al., 2013).

For ionization of protein samples, the matrix solution is mixed with the analyte, enabling formation of protein spectra with specific molecular weight ranges. The matrix consists of crystallized molecules, and the most frequently used are alpha-matrix (alpha-4-cyano-4hydroxycinnamic acid, CHCA), sinapinic acid (3,5-dimethoxy-4-hydroxycinnamic acid, SA), and 2,5-dihydroxybenzoic acid (DHB) (Beavis et al., 1989; Beavis et al., 1992; Strupat et al., 1991). Matrices are often specific to Gram staining of bacteria, therefore allowing identification of mixed cultures with different Gram types (Evason et al., 2001). However, as variations in sample preparation can influence mass spectra, standardized protocols need to be applied in regards to incubation time, type of culture media, matrix, extraction solvent, salt content and deposition method (Ruelle et al., 2004; Emami et al., 2012). 


\section{Comparison with conventional and molecular identification procedures}

The prerequisite for any microbial identification is a rapid and reliable test which can be conducted in various types of clinical, environmental, veterinary and other studies. Tedious biochemical and phenotypical procedures, which use both manual and automated platforms, are utilized alone or in addition to molecular methods. Although some of these tests are straightforward, the complete identification usually takes at least one day, and they often do not provide a reliable answer in routine microbiological identification (Table 1). With MALDI-TOF MS, aside from the easy data analysis, time to result is a few minutes after culture, while running costs are low (Lavigne et al., 2013), esp. when compared with some of the conventional identification systems. For example (in euros/minutes), API systems on average take 4.66.0/1080-2880, BD Phoenix 12.65/300-1200, Vitek systems 5.9-8.23/300-480, and MALDI-TOF MS 1.43/6-6,5 (Seng et al., 2009). Costs and time-frames for 16S rRNA analyses may be substantial per isolate, depending on sequences and repetitions (Clarridge, 2004; Justesen et al., 2010). There are a number of available conventional diagnostic microbiological tools which were compared for their identification capacity and reliability with MALDI-TOF MS, mostly for clinically relevant bacteria (Risch et al., 2010; van Veen et al., 2010; Saffert et al., 2011; Alvarez-Buylla et al., 2012; El-Bouri et al., 2012; Fang et al., 2012; Meex et al., 2012; Zangenah et al., 2012; Caretto et al., 2013; Jamal et al., 2013; Almuzara et al., 2015, to name a few recent studies).

Some commercially available diagnostic tests form a part of routine laboratory diagnostics, such as API 20E, API ZYM, API 20NE, API 20AN, API $50 \mathrm{CH}$, API Rapid ID 32 (bioMerieux, Marcy-l'Etoile, France), Biolog MicroPlates GN2, GP2, AN (Biolog, Inc., Hayward, CA, USA), Enterotubes, BBL Crystal E/NF (Becton-Dickinson \& Company, Franklin Lakes, NJ, USA), Bionor Aqua (Bionor, Skien, Norway) systems and some others (Topić Popović et al., 2007). Of these, API 20E rapid identification system has been the most widely used in identification of Enterobacteriaceae and other non-fastidious Gram-negative bacilli. Conventional methods result in fewer species identification and more major errors than MALDITOF MS in discrimination of both Gram-negative and Gram-positive bacteria (van Veen et al., 2010). For Gram-positive anaerobic cocci only MALDI-TOF MS allowed accurate identification to the species level (Kierzkowska et al., 2013) when compared to other diagnostic panels. The use of MALDI-TOF MS was reliable in identification of close to 300 colonies isolated through different seasons and various points from water sources, when compared to API-based identifications and even to 16S rRNA gene sequencing (Sala-Comorera et al., 2016). One of the reasons that mass spectrometry outperforms API systems is that the current taxonomic database of the MALDI Biotyper system recognizes species of different taxonomic status that have not been updated in the apiweb database (Kierzkowska et al., 2013). Because of the open platform design, additional spectra can be uploaded to the Bruker Biotyper database, achieving identification of species previously possible only with 16S rRNA sequencing (Saffert et al., 2011). Overall, conventional tests are rather time-consuming metabolic reactions, which require experience with morphological and observer-dependent judgments (Risch et al., 2010). Adversely, MALDI-TOF MS can be used as the initial method for identification, before Gram staining and any biochemical profiling, when using a database which includes 10 reference spectra per bacterial species and an identification score $\leq 1.9$ (Seng et al., 2009). 
PCR is less prone to errors in comparison to conventional methods for identification of bacteria that rely mostly on phenotypic and morphological features of strains (Campos Braga et al., 2013). However, although DNA is a characteristic biomarker for any microorganism, there is just one copy per cell if not amplified. When analyzing an intact bacterium, it has to be extracted, separated and amplified, and that is why molecular methods are generally considerably more expensive and slower to perform, while proteins provide the most characteristic biomarkers accessible for identification and discrimination of bacteria (Fenselau and Demirev, 2001). In comparison with standard 16S rRNA sequencing, MALDI-TOF MS provided similar results, in some cases superior and enabling a taxonomic classification to the subspecies level (Hausdorf et al., 2013). Often, MALDI-TOF MS and 16S rRNA are run to confirm the identity of the species. In freshwater samples, accurate findings of isolated strains were reported with both tests for waterborne pathogens in aquatic environments (Salmonella, Legionella, Yersinia, Campylobacter) and fecal indicator bacteria, including E. coli and Enteroccocus (Thevenon et al., 2012; Lee et al., 2014). However, MALDI-TOF MS surpassed both phenotypic and genotypic approaches for identification of Pseudomonas and Bacillus genera, where 16S rRNA identified to the species level only $50 \%$ of strains, while MS fingerprinting identified $76 \%$ (Böhme, 2013). Molecular techniques are needed for identification of species within the Acinetobacter genus, although MALDI-TOF MS gives a correct identification of A. baumanii (Alvarez-Buylla et al., 2012). Recent findings have, however, revealed that MALDI-TOF MS is unsuitable to discriminate A. baumanii clones (Sousa et al., 2015). Non-fermenting bacteria in general (taxonomically heterogeneous genera Pseudomonas, Burkholderia, Stenotrophomonas etc.) are frequently misidentified by classical methods, and for them 16S rRNA provides less accurate results at the species level. For that reason, MALDI-TOF MS reference databases for non-fermenters are constantly updated (Campos Braga et al., 2013), giving a high reproducibility for identification of these bacteria, with $98.75 \%$ of correct species identification (LiPuma, 2010). Enterobacteriaceae and Cronobacter were assigned $100 \%$ to the species level with both 16S rRNA and MALDI-TOF MS, but the MALDI-TOF MS identifications were more discriminating and unequivocal in the work of Zhu et al. (2011). Earlier studies attributed 16S rRNA gene sequencing the title of a gold standard, although it is known that different sequences within a short base pair stretch may question species alignment based on metabolomic identification (Risch et al., 2010). Furthermore, 16S rRNA is not introduced in routine microbiology laboratories, however MALDI-TOF MS, due to its effectiveness and time-saving properties, is making way to routine laboratory diagnostics.

\section{Potential aquatic pathogens}

Microbial communities in the environment are extremely diverse; however waters and animals that inhabit them are of particular interest. For example, the etiology of bacterial diseases in wild aquatic animals is often improperly understood, as the study of aquatic animals' diseases mainly concentrates on problems relating to fish farms. The ecology of such pathogens is understudied since it is often unclear whether a bacterium is a representative of the natural aquatic microflora or is restricted to organisms, and what the possible role of pollution in the outbreaks of diseases is (Austin and Austin, 1999). Table 2 lists the most important aquatic bacteria that may be either a part of the normal flora of healthy aquatic species, or pathogenic to their hosts. In stressed animals these bacteria may override their defense mechanisms and cause infections. Most of the 
bacteria presented in Table 2 can be found worldwide and some of them have also been isolated from humans.

There is a growing awareness that a number of aquatic bacteria (pathogens and/or commensals) may infect humans and cause zoonotic diseases. Although comprehensive statistics still lack, the number of cases of human diseases traceable to aquatic animals is relatively small (Austin, 2010). Transmission to humans occurs mostly from handling, via wounds or is foodborne or waterborne involving a direct entry into the digestive system (Austin, 2010; Haenen et al., 2013). Of bacteria generally presented as fish related zoonoses, only the following are well supported as zoonoses in the strict sense, causing diseases in both aquatic animals and humans: Mycobacterium spp., Streptococcus iniae, Clostridium botulinum, Vibrio vulnificus (Gauthier, 2015). Other reported sporadic human infections are associated with Aeromonas hydrophila, Edwardsiella tarda, Salmonella paratyphi B var. Java, Grimontia hollisae, Photobacterium damselae subsp. damselae, $V$. alginolyticus, $V$. harveyi, $V$. fluvialis, and $V$. mimicus (Austin, 2010; Weir et al., 2012; Haenen et al., 2013). These organisms are widespread in freshwater, estuarine and marine environments, on invertebrates, mollusks, cephalopods, fish and other aquatic animals. New pathogenic bacterial species are frequently reported, thus the range of zoonoses may also increase, requiring prompt and accurate identification and diagnosis, particularly in cases of infections which turn into septicemia or life-threatening conditions.

\section{MALDI-TOF MS applicability for environmental isolates (water, biota)}

Bacteria represent the largest reservoir of biodiversity to be studied, as they are estimated to number over $10^{30}$ worldwide (Schloss and Handelsman, 2004). However, less than $1 \%$ of the bacteria from natural habitats can be grown in laboratory (Dykhuizen, 1997). The accuracy and speed in obtaining data makes MALDI-TOF MS a powerful tool of significance for environmental microbiology (Donohue et al., 2006). It has been successfully applied to identification of clinical bacterial isolates, but its application in an ecological context is rare (Hausdorf et al., 2013). MALDI-TOF MS was applied in identification of possible contributing sources to fecal contamination of surface waters (Siegrist et al., 2007). Typically, methods for bacterial source tracking use labor-intensive, time-consuming phenotypic traits or genotypic profiles, but MALDI-TOF MS in the work of Siegrist et al. (2007) discriminated closely related environmental strains of $E$. coli and characterized them according to their respective specific sources, which is essential for safeguarding public health and managing water resources.

A few studies clearly demonstrate the usefulness of rapid discrimination of environmental and particularly aquatic bacteria, mostly Vibrio and Aeromonas strains (Donohue et al., 2007; Benagli et al., 2012; Eddabra et al., 2012, Schirmeister et al., 2014; Topić Popović et al., 2015). Koubek et al. (2012) recommend whole-cell MALDI-TOF MS over 16S rRNA for rapid screening and discrimination of various environmental bacterial isolates. MALDI-TOF MS was also used to aid in discrimination of two closely related Vibrio species, $V$. furnissii and $V$. fluvialis, both emerging human pathogens, associated with consumption of seafood or drinking of contaminated water (Schirmeister et al., 2014). It was also applied in rapid discrimination of environmental Vibrio species from wastewater samples (Eddabra et al., 2012), where it proved capable of differentiating all 30 closely related Vibrio isolates. MALDI-TOF MS was successfully used for interspecific differentiation of Vibrio strains extracted from samples of boat 
ballast waters, detecting a complete range of pathogenic and non-pathogenic strains (Telesmanitch et al., 2014).

Of particular interest are aeromonads, potential animal and human pathogens occurring in almost every aquatic environment, as it was found that environmental isolates of Aeromonas have a wider phenotypic diversity than isolates from clinical samples (Donohue et al., 2007). In a study investigating the potential for using the $\mathrm{m} / \mathrm{z}$ signature of known Aeromonas strains to speciate unknown environmental isolates, the aeromonads atypical of the species to which they were assigned biochemically were not concordant with the MALDI-TOF MS assignment. However, it was shown that closely related genera have unique $\mathrm{m} / \mathrm{z}$ signatures not overlapping with Aeromonas strains (Donohue et al., 2007). Although it was indicated that MS can be a very useful tool for aeromonad speciation, as also demonstrated in the work of Benagli et al., (2012), who established that the MS distinguished well between genera, species and aeromonad strains, a later study (Vávrová et al., 2015) found that MALDI-TOF MS is not a reliable diagnostic technique for environmental aeromonads. That was concluded on account of high percentage of false-positive, incorrect, and uncertain identification results, both of newly described aeromonads and of pathogenic ones. To the contrary, Lamy et al. (2011) established that genuslevel accuracy of clinical and environmental aeromonads identified by mass spectrometry was $100 \%$, while species-level accuracy reached 90.6 \%. Some Aeromonas species are known for their complex taxonomy and limited possibilities of identification to the species level. One of such examples is $A$. media, having a wider $\mathrm{m} / \mathrm{z}$ signature range than other species, thus more strains should be added to the databases to best represent this bacterium (Donohue et al., 2007). In a recent study on aeromonads from treated wastewater and fish, we observed that among 24 genera isolated from water, sludge and fish samples, aeromonads were the most represented group (Topić Popović et al., 2015). Also, the identification match between conventional identification systems and MALDI-TOF MS was also the highest for aeromonads to the genus level, with $A$. veronii as the most frequent aeromonad identified. Over $6 \%$ of Aeromonas in our study were identified as $A$. bestiarum, but were assigned as $A$. hydrophila by conventional methods. Excluding the database deficiency, it is possible that this identification disparity can be attributed to close relatedness of the two species, belonging to the same phenogroup, described as the A. hydrophila complex (Martino et al., 2011). MALDI-TOF MS can however assure their good discrimination at the genospecies level comparable with the $\operatorname{gyr} B$ gene sequencing as it clusters well differentiated A. bestiarum and A. hydrophila (Benagli et al., 2012).

The need for comparison of MALDI-TOF MS data with results obtained from phenotypic and genotypic identification methods is still important for identification of environmental isolates. We confirmed that in our study where we isolated bacteria from tissues of apparently healthy freshwater crayfish (Topić Popović et al., 2014). From 25 relevant isolates, only one matched to the species when compared with conventional methods (Hafnia alvei), while API 20E and MALDI-TOF MS identified $60.86 \%$ identically to the genus. The highly probable species identification with MALDI-TOF MS was mostly related to Pseudomonas, Bacillus and Hafnia (Figure 1). The most prevalent genus identified was Pseudomonas, one of the most frequently isolated non-fermenters from crayfish, and a potential pathogen. Although half of the isolates were pseudomonads, only 39.13 \% were assigned to the species level with both systems. Commercial biochemical test (Rapid 32 ID Strep) was also used in comparison with MALDITOF MS in order to identify Enterococcus spp. isolated from various water environments, and in $85 \%$ they both gave concordant identification results, while the rest were not detectable by the biochemical system (Taučer-Kapteijn et al., 2013). In discrepant identification outputs, the 16S 
rRNA gene sequencing confirmed the MALDI-TOF MS identification. Interestingly, identification of $V$. parahaemolyticus isolated from sea water, shellfish and sediments was consistent through Vitek-2 system and MALDI-TOF MS in the work of Malainine et al. (2013). MALDI-TOF MS was used to further discriminate between closely related environmental $V$. parahaemolyticus strains, and when placed at a $10 \%$ threshold of the whole diversity, isolates differed by at least three mass peaks, revealing a larger biodiversity when analyzed through mass spectra of abundant proteins (Malainine et al., 2013).

Identification of waterborne bacteria by MALDI-TOF MS is more straightforward when conducting identification of microbial pathogens that occur in water, such as Helicobacter pylori, Salmonella typhimurium, Yersinia enterolitica, Legionella pneumophila, and Campylobacter jejuni, since MALDI-TOF MS identification results were well correlated with 16S rRNA gene sequencing identification in the work of Lee et al. (2014). When differentiating the unknown flavobacteria from freshwater and biofilm samples in order to rapidly group them according to overall phenotypic resemblance, the peak profile of only one Flavobacterium species was available for comparison, due to the lack of reference organisms (Brambilla et al., 2007). However, more than 30 strains clustered around this strain at similarity levels up to $50 \%$, showing rich diversity with peak similarities up to $80 \%$, and were confirmed with 16S rRNA gene sequencing as genus Flavobacterium. Affiliation with that genus on the basis of MALDITOF MS was further confirmed with flexirubin and fatty acid analysis (Brambilla et al., 2007). The challenge is also to differentiate between environmental and clinical isolates of the same bacterial species since they, although of the same molecular type, might be markedly diverse in enzyme activities and cytolethality. In order to determine whether MALDI-TOF MS can group Burkholderia pseudomallei isolates according to their respective sources (environmental vs. clinical), Niyompanich and coworkers (2014), generated a principal component analysis of the raw $B$. pseudomallei mass spectra and a dendrogram, demonstrating that the isolates are intermixed and not forming distinct groups. However, although not clustered according to their sources, most of the isolates were differentiated according to their respective source groups using the whole-cell MALDI-TOF MS by constructing an average mass spectrum of the environmental bacterial set and of the clinical set. The mass spectra of the two groups demonstrated high similarity in peak patterns, but differed in peak intensities (Niyompanich et al., 2014), therefore allowing source differentiation. Thus, examination of isolates in terms of source categorization by MALDI-TOF MS could be altered relative to a variety of tested bacteria.

Grouping of environmental isolates from unknown environments is essential in biodiversity studies where large numbers of strains need to be isolated on different growth media, particularly since easily isolated organisms constitute a minor fraction of total bacterial community in environmental samples (Dieckmann et al., 2005). MALDI-TOF MS was found a powerful tool for a high-throughput dereplication of environmental samples, a process of recognizing identical isolates at a specific taxonomic level and grouping them accordingly (Ichiki et al., 2008; Ghyselinck et al., 2011), Dereplication involves rapid screening of all isolates in order to recongnize and eliminate those that represent the same taxon (Spitaels et al., 2016). Today, MALDI-TOF MS is used as a dereplication tool for grouping isolates at the species level, while groups of spectra are generated mostly using algorithms based on the presence or absence of peaks, or on peak intensities (Spitaels et al., 2016). For dereplication purposes it was first used on bacteria isolated from marine sponges (Dieckmann et al., 2005), and was also successfully applied in extreme surroundings, such as hypersaline environments, where it was used for dereplication of halophilic prokaryotes (Munoz et al., 2011; Viver et al., 2015). 
MALDI-TOF MS has the capacity to simplify both identification and dereplication, as mass spectra of isolates that cannot be identified directly can be clustered, and representative bacteria can be subjected to further polyphasic identification (Spitaels et al., 2016; Kopcakova et al., 2014).

At present, MALDI-TOF MS methodology for characterization of bacteria greatly varies through differences in sample preparation methods, matrix solutions, organic solvents, acquisition methods and data analysis methods (De Bruyne et al., 2011). The standard protocols for MALDI-TOF MS must be established in order to reduce data variation between laboratories and assure reproducibility (Niyompanich et al., 2014). Generally, it can be concluded that for aquatic/environmental isolates, MALDI-TOF MS still yields lower identification precision than in routine, expected, clinical samples with defined databases. Although most MS databases relate to bacteria with relevance mostly to the medical field, the number and diversity of reference strains cataloged in the mass spectral libraries are being expanded, particularly in order to precisely identify unknown environmental isolates, and also to minimize the possible overlapping of mass ions from other genera (Donohue et al., 2006; Schumann and Maier, 2014; Zhang et al., 2015), therefore it is expected that applicability of MALDI-TOF MS for environmental isolates will soon reach its full potential.

\section{Overview and future prospects}

The advantages of the MALDI-TOF MS method for identification of environmental aquatic bacteria are numerous. It is the most promising technology for microbiological analyses. Sample preparation is minimal as it analyzes whole bacterial cells. It provides excellent accuracy and specificity with high throughput, can easily be adapted to bacteriology laboratory workflow, data analysis is easy, time to result is just a few minutes after cultivation of the organism, which reduces the possibility of contamination, while running costs are low (Donohue et al., 2006; Seng et al., 2009; Sauer and Kliem, 2010; Böhme et al., 2013; Lavigne et al., 2013). Databases are constantly updated and the possibilities to identify unknown, rare and fastidious bacteria are increasing. Some limitations of the method also have to be addressed, the most important one still being the incompleteness of databases, which need expansion, especially regarding the environmental isolates (van Veen et al., 2010; Lamy et al., 2011; Kopcakova et al., 2014). There is a need for tested protocols on preparation of fastidious bacteria and optimization of measurement conditions (Schumann and Maier, 2014). Also, identification requires relatively large number of cultivated bacteria (an intact colony), while the methods offers a limited possibility to identify bacteria directly from tissues. The technique is confident with pure colonies, while it is not reliable with polymicrobial material (Lavigne et al., 2013). The reproducibility and accuracy of MS can be influenced by culture media, growth time, bacterial concentration, sample preparation, calibration and matrices (Demirev et al., 1999; Mazzeo et al., 2006; Saffert et al., 2011).

Novel applications of the MS will certainly be a step further in microbiology. Although MALDI-TOF MS is still limited in the number of detectable targets for strain characterization (Karlsson et al., 2015), efforts have been made to increase the taxonomic resolution of the MALDI-TOF MS, using library-based and bioinformatics-enabled approaches to enhance strain categorization, differentiation and identification of bacteria at the strain level. Bioinformatics- 
enabled approaches facilitate strain profiling through intact biomarker identification, bottom-up, and top-down procedures, not suffering limitations of culture conditions and sample preparation, thus enhancing the strain resolution possibilities of the method (Fenselau and Demirev, 2001; Kok et al., 2013; Sandrin et al., 2013). Availability of bioinformatics tools for database searches allows not only secure identification, but also high reproducibility, giving almost real-time identification results and possibilities to distinguish between bioagents, pathogenic and nonpathogenic species (Campos Braga et al., 2013). For example, MALDI-TOF MS was used to differentiate pathogenic and non-pathogenic Leptospira strains, by categorizing the super reference spectra and the major spectra projection dendrogram into groups, thus proving an important tool in surveillance of this omnipresent and zoonotic organism (Xiao et al., 2015). Furthermore, MALDI-TOF MS not only facilitates the detection of novel species, but can also reveal taxonomic anomalies (Spitaels et al., 2016; Wieme et al., 2014).

A new promising application of the method relates to non-culture identification of bacteria directly from samples containing mixed cultures (fluids, blood, urine), and protocols are being developed to improve the sensitivity of MS for that purpose (Opota et al., 2015), which is a great prospect for non-lethal health examination of farmed fish. Not all organisms in a mixed culture are identifiable, for example the analytical sensitivity in blood culture varied between 66 $\%$ and $76 \%$, with a dominant precision of about $90 \%$ for identification of Gram-negative bacteria (Lavigne et al., 2013). Barnini et al. (2015) developed a method for MALDI-TOF MS rapid identification of Gram-negative bacteria and Gram-positive cocci from blood cultures, having higher precision and reliable results.

Aside from identification of bacteria, MALDI-TOF MS may be formulated for recognition of some crucial surface-associated virulence factors, based on the selective determination of presence or absence of $\mathrm{m} / \mathrm{z}$ peaks (Bittar et al., 2009). A novel effector that contributes to virulence of the major causative agent of fish hemorrhagic septicemia and human pathogen, Edwardsiella tarda, was identified by MALDI-TOF MS (Xie et al., 2015). The most challenging application of MALDI-TOF MS is the ability to detect bacterial strains with developed antibiotic resistance (Kok et al., 2013). Different approaches were applied regarding particular antibiotics and microorganism classes. In Gram-negative bacteria, plasmid-encoded $\beta$ lactamases are the greatest contributors to antibiotic resistance, hydrolyzing the $\beta$-lactam structure of certain antibiotics, which leads to their inactivation (Kostrzewa et al., 2013). MALDI-TOF MS can be applied to measure enzyme-mediated, time-dependent hydrolysis of the $\beta$-lactam ring structure of penicillin $G$ and ampicillin, as well as inhibition of hydrolysis by clavulanic acid (Hooff et al., 2012). When performed with growth media containing isotopically labeled amino acids, MALDI-TOF MS facilitates detection of resistant bacteria in less than three hours. Bacteria incorporate labeled amino acids, which increases their protein masses and shifts their peaks in spectral profile. In the presence of antibiotics, only resistant bacteria are able to grow and incorporate the labeled amino acids (Sparbier et al., 2013).

There is a number of evidences demonstrating reliability of MALDI-TOF MS when compared with other established methods, particularly 16S rRNA sequencing, and it is thus finding its way in environmental applications. As a rapid and inexpensive tool, it may serve for detection of bacteria for monitoring purposes and research, for health assessments and therapy considerations of aquatic organisms, as well as identification of bacterial contaminants and emerging indicator organisms that impact aquatic environments, acting as an early warning system for determination of causes of their impaired health. 


\section{References}

Almuzara, M., Barberis, C., Traglia, G., Famiglietti, A., Ramirez, M.S., Vay, C., 2015.

Evaluation of matrix-assisted laser desorption ionization-time-of-flight mass spectrometry for species identification of nonfermenting Gram-negative bacilli. J. Microbiol. Methods. 112, 2427.

Alvarez-Buylla, A., Culebras, E., Picazo, J.J., 2012. Identification of Acinetobacter species: Is Bruker biotyper MALDI-TOF mass spectrometry a good alternative to molecular techniques? Infect. Genet. Evol. 12 (2), 345-349.

Amalfitano, S., Coci, M., Corno, G., Luna, G.M., 2014. A microbial perspective on biological invasions in aquatic ecosystems. Hydrobiologia 746 (1), 13-22.

Anhalt, J.P., Fenselau, C., 1975. Identification of bacteria using mass-spectrometry. Anal. Chem. 47 (2), 219-225.

Austin, B., Austin, D.A., 1999. Bacterial fish pathogens: Disease of farmed and wild fish, 3rd edn. Springer-Praxis Publishing, Chichester

Austin, B., 2010. Vibrios as causal agents of zoonoses. Vet. Microbiol. 140 (3-4), 310-317.

Bailey, D., Diamandis, E.P., Greub, G., Poutanen, S.M., Christensen, J.J., Kostrzew, M., 2013. Use of MALDI-TOF for diagnosis of microbial infections. Clin. Chem. 59 (10), 1435-1441.

Barnini, S., Ghelardi, E., Brucculeri, V., Morici, P., Lupetti, A., 2015. Rapid and reliable identification of Gram-negative bacteria and Gram-positive cocci by deposition of bacteria harvested from blood cultures onto the MALDI-TOF plate. BMC Microbiol. 15: 124. doi: 10.1186/s12866-015-0459-8.

Beavis, R.C., Chait, B.T., Fales, H.M., 1989. Cinnamic acid derivatives as matrices for ultraviolet laser desorption-MS of proteins. Rapid Commun. Mass Spectrom. 3 (12), 432-435.

Beavis, R.C., Chaudhary, T., Chait, B.T., 1992. $\alpha$-cyano-4-hydroxycinnamic acid as a matrix for matrix-assisted laser desorption MS. Org. Mass Spectrom. 27 (2), 156-158.

Benagli, C., Demarta, A., Caminada, A., Ziegler, D., Petrini, O., Tonolla, M., 2012. A rapid MALDI-TOF MS identification database at genospecies level for clinical and environmental Aeromonas strains. PLoS One 7(10): e48441. doi:10.1371/journal.pone.0048441.

Bittar, F., Ouchenane, Z., Smati, F., Raoult, D., Rolain, J.M., 2009. MALDI-TOF-MS for rapid detection of staphylococcal Panton-Valentine leukocidin. Int. J. Antimicrob. Agents 34, 467-470.

Böhme, K., Fernández-No, I.C., Pazos, M., Gallardo, J.M., Barros-Velázquez, J., Cañas, B., Calo-Mata, P., 2013. Identification and classification of seafood-borne pathogenic and spoilage 
bacteria: 16S rRNA sequencing versus MALDI-TOF MS fingerprinting. Electrophoresis 34 (6), 877-887.

Brambilla, E., Päuker, O., Cousin, S., Steiner, U., Reimer, A., Stackebrandt, E., 2007. High phylogenetic diversity of Flavobacterium spp. isolated from a hardwater creek, Harz Mountains, Germany. Org. Divers. Evol. 7 (2), 145-154.

Bright, J.J., Claydon, M.A., Soufian, M., Gordon, D.B., 2002. Rapid typing of bacteria using matrix-assisted laser desorption ionisation time-of-flight mass spectrometry and pattern recognition software. J. Microbiol. Methods 48 (2-3), 127-138.

Buller, N.B., 2004. Bacteria from fish and other aquatic animals: A practical identification manual. CABI Publishing, Wallingford, UK, pp 328.

Campos Braga, P.A., Tata, A., Goncalves dos Santos, V., Barreiro, J.R., Vilczaki Schwab, N., Veiga dos Santos, M., Eberlin, M.N., Ramires Ferreira, C., 2013. Bacterial identification: from the agar plate to the mass spectrometer. RSC Adv. 3, 994-1008.

Caretto, E., Bardaro, M., Russello, G., Mirra, M., Zuelli, C., Barbarini, D., 2013. Comparison of the Staphylococcus QuickFISH BC test with the tube coagulase test performed on positive blood cultures for evaluation and application in a clinical routine setting. J. Clin. Microbiol. 51 (1), 131-135.

Clarridge, J.E., 2004. Impact of 16S rRNA gene sequence analysis for identification of bacteria on clinical microbiology and infectious diseases. Clin. Microbiol. Rev. 17 (4), 840-862.

Claydon, M.A., Davey, S.N., Edwards-Jones, V., Gordon, D.B., 1996. The rapid identification of intact microorganisms using mass spectrometry. Nat. Biotechol. 14 (11), 1584-1586.

De Bruyne, K., Slabbinck, B., Waegeman, W., Vauterin, P., De Baets, B., Vandamme, P., 2011. Bacterial species identification from MALDI-TOF mass spectra through data analysis and machine learning. Syst. Appl. Microbiol. 34 (1), 20-29.

Demirev, P.A., Ho, Y.-P., Ryzhov, V., Fenselau, C., 1999. Microorganism identification by mass spectrometry and protein database searches. Anal. Chem. 71 (14), 2732-2738.

Dieckmann, R., Graeber, I., Kaesler, I., Szewzyk, U., von Döhren, H., 2005. Rapid screening and dereplication of bacterial isolates from marine sponges of the Sula Ridge by Intact-Cell-MALDITOF mass spectrometry (ICM-MS). Appl. Microbiol. Biotechnol. 67 (4), 539-548.

Donohue, M.J., Smallwood, A.W., Pfaller, S., Rodgers, M., Shoemaker, J.A., 2006. The development of a matrix-assisted laser desorption/ionization-mass spectrometry-based method for the protein fingerprinting and identification of Aeromonas species using whole cells. J. Microbiol. Methods 65 (3), 380-389. 
Donohue, M.J., Best, J.M., Smallwood, A.W., Kostich, M., Rodgers, M., Shoemaker, J.A., 2007. Differentiation of Aeromonas isolated from drinking water distribution systems using matrixassisted laser desorption/ionization-mass spectrometry. Anal. Chem. 79 (5), 1939-1946.

Dykhuizen, D.E. 1997. Santa Rosalia revisited: Why are there so many species of bacteria? Anton. Leeuw.73, 25-33.

Eddabra, R., Prévost, G., Scheftel, J.M., 2012. Rapid discrimination of environmental Vibrio by matrix-assisted laser desorption ionization time-of-flight mass spectrometry. Microbiol. Res. 167 (4), 226-230.

El-Bouri, K., Johnston, S., Rees, E., Thomas, I., Bome-Mannathoko, N., Jones, C., Reid, M., Ben-Ismaeil, B., Davies, A.P., Harris, L.G., Mack, D., 2012. Comparison of bacterial identification by MALDI-TOF mass spectrometry and conventional diagnostic microbiology methods: Agreement, speed and cost implications. Br. J. Biomed. Sci. 69 (2), 47-55.

Emami K., Askari V., Ullrich M., Mohinudeen K., Anii A.C., Khandeparker, L., Burgess, J.G., Mesbahi, E., 2012. Characterization of bacteria in ballast water using MALDI-TOF mass spectrometry. PLoS One 7(6): e38515. doi: 10.1371/journal.pone.0038515.

Evason, D.J., Claydon, M.A., Gordon, D.B., 2001. Exploring the limits of bacterial identification by intact cell-mass spectrometry. J. Am. Soc. Mass Spectrom. 12 (1), 49-54.

Fang, H., Ohlsson, A.-K., Ullberg, M., Özenci, V., 2012. Evaluation of species-specific PCR, Bruker MS, VITEK MS and the VITEK 2 system for the identification of clinical Enterococcus isolates. Eur. J. Clin. Microbiol. Infect. Dis. 31 (11), 3073-3077.

Fenselau, C., Demirev, P.A., 2001. Characterization of intact microorganisms by MALDI mass spectrometry. Mass Spectrom. Rev. 20 (4), 157-171.

Gauthier, D.T., 2015. Bacterial zoonoses of fishes: A review and appraisal of evidence for linkages between fish and human infections. Vet. J. 203 (1), 27-35.

Ghyselinck J., Van Hoorde, K., Hoste B., Heylen, K., De Vos, P., 2011. Evaluation of MALDITOF MS as a tool for high-throughput dereplication. J. Microbiol. Methods. 86 (3), 327-336.

Haenen, O.L.M., Evans, J.J., Berthe, F., 2013. Bacterial infections from aquatic species:

Potential for and prevention of contact zoonoses. Rev. Sci. Tech. Off. Int. Epiz. 32 (2), 497-507.

Hausdorf, L., Mundt, K., Winzer, M., Cordes, C., Fröhling, A., Schlüter, O., Klocke, M., 2013. Characterization of the cultivable microbial community in a spinach-processing plant using MALDI-TOF MS. Food Microbiol. 34 (2), 406-411.

Holland, R.D., Wilkes, J.G., Rafii, F., Sutherland, J.B., Persons, C.C., Voorhees, K.J., Lay, Jr J.O., 1996. Rapid identification of intact whole bacteria based on spectral pattern using matrix- 
assisted laser desorption/ionization with time-of-flight mass spectrometry. Rapid Commun. Mass. Spectrom. 10 (10), 1227-1232.

Hooff, G.P., van Kampen, J.J., Meesters, R.J., van Belkum, A., Goessens, W.H., Luider, T.M., 2012. Characterization of $\beta$-lactamase enzyme activity in bacterial lysates using MALDI-mass spectrometry. J. Proteome Res. 11 (1), 79-84.

Ichiki, Y., Ishizawa, N., Tamura, H., Teramoto, K., Sato, H., Yoshikawa, H., 2008. Environmental distribution and novel high-throughput screening of APEO-degrading bacteria using matrix-assisted laser desorption ionization-time-of-flight mass spectrometry (MALDIMS). J. Pestic. Sci. 33 (2), 122-127.

Jamal, W.Y., Shahin, M., Rotimi, V.O., 2013. Comparison of two matrix-assisted laser desorption/ionization-time of flight (MALDI-TOF) mass spectrometry methods and API 20AN for identification of clinically relevant anaerobic bacteria. J. Med. Microbiol. 62, 540-544.

Justesen, U.S., Skov, M.N., Knudsen, E., Holt, H.M., Søgaard, P., Justesen, T., 2010. 16S rRNA gene sequencing in routine identification of anaerobic bacteria isolated from blood cultures. J. Clin. Microbiol. 48 (3), 946-948.

Karas, M., Bachmann, D., Hillenkamp, F., 1985. Influence of the wavelength in high-irradiance ultraviolet laser desorption mass spectrometry of organic molecules. Anal. Chem. 57 (14), 29352939.

Karlsson, R., Gonzales-Siles, L., Boulund, F., Svensson-Stadler, L., Skovbjerg, S., Karlsson, A., Davidson, M., Hulth, S., Kristiansson, E., Moore, E.R.B., 2015. Proteotyping: Proteomic characterization, classification and identification of microorganism - A prospectus. Syst. Appl. Microbiol. 38 (4), 246-257.

Kierzkowska, M., Majewska, A., Kuthan, R.T., Sawicka-Grzelak, A., Mynarczyk, G., 2013. A comparison of Api 20A vs MALDI-TOF MS for routine identification of clinically significant anaerobic bacterial strains to the species level. J. Microbiol. Methods 92 (2), 209-212.

Kok, J., Chen, S.C.A., Dwyer, D.E., Iredell, J.R., 2013. Current status of matrix-assisted laser desorption ionization-time of flight mass spectrometry in the clinical microbiology laboratory. Pathology 45 (1), 4-17.

Kopcakova, A., Stramova, Z., Kvasnova, S., Godany, A., Perhacova, Z., Pristas, P., 2014. Need for database extension for reliable identification of bacteria from extreme environments using MALDI-TOF mass spectrometry. Chem. Pap. 68 (11), 1435-1442.

Kostrzewa, M., Sparbier, K., Maier, T., Schubert, S., 2013. MALDI-TOF MS: An upcoming tool for rapid detection of antibiotic resistance in microorganisms. Proteomics Clin. Appl. 7 (11-12), 767-778. 
Koubek, J., Uhlik, O., Jecna, K., Junkova, P., Vrkoslavova, J., Lipov, J., Kurzawova, V., Macek, T., Mackova, M., 2012. Whole-cell MALDI-TOF: Rapid screening method in environmental microbiology. Int. Biodeter. Biodegr. 69, 82-86.

Lamy, B., Kodjo, A., Laurent, F., 2011. Identification of Aeromonas isolates by matrix-assisted laser desorption ionization time-of-flight mass spectrometry. Diagn. Microbiol. Infect. Dis. 71 (1), 1-5.

Lavigne, J.-P., Espinal, P., Dunyach-Remy, C., Messad, N., Pantel, A., Sotto, A., 2013. Mass spectrometry: a revolution in clinical microbiology? Clin. Chem. Lab. Med. 51 (2), 257-270.

Lay, Jr J.O., 2001. MALDI-TOF mass spectrometry of bacteria. Mass Spectrom. Rev. 20 (4), 172-194.

Lee, Y.-J., Park, J.-G., Rhee, O.-J., Lee, G.-C., 2014. Identification of waterborne microbial pathogens by matrix-assisted laser-desorption/ionization time-of-flight mass spectrometry and the Biotyper 2.0 databases. J. Pure Appl. Microbiol. 8 (5), 3525-3530.

LiPuma, J.J., 2010. The changing microbial epidemiology in cystic fibrosis. Clin. Microbiol. Rev. 23 (2), 299-323.

Malainine, S.M., Moussaoui, W., Prévost, G., Scheftel, J-M., Mimouni, R., 2013. Rapid identification of Vibrio parahaemolyticus isolated from shellfish, sea water and sediments of the Khnifiss lagoon, Morocco, by MALDI-TOF mass spectrometry. Lett. Appl, Microbiol. 56 (5), 379-386.

Martino, M.E., Fasolato, L., Montemurro, F., Rosteghin, M., Manfrin, A., Patarnello, T., Novelli, E., Cardazzo, B., 2011. Determination of microbial diversity of Aeromonas strains on the basis of multilocus sequence typing, phenotype, and presence of putative virulence genes. Appl. Environ. Microbiol. 77 (14), 4986-5000.

Mazzeo, M.F., Sorrentino, A., Gaita, M., Cacace, G., Di Stasio, M., Facchiano, A., Comi, G., Malorni, A., Siciliano, R.A., 2006. Matrix-assisted laser desorption ionization-time of flight mass spectrometry for the discrimination of food-borne microorganisms. Appl. Environ. Microbiol. 72 (2), 1180-1189.

Meex, C., Neuville, F., Descy, J., Huynen, P., Hayette, M.-P., De Mol, P., Melin, P., 2012. Direct identification of bacteria from BacT/ALERT anaerobic positive blood cultures by MALDI-TOF MS: MALDI Sepsity per kit versus an in-house saponin method for bacterial extraction. J. Med. Microbiol. 61, 1511-1516.

Munoz R., Lòpez-Lòpez A., Urdiain M., Moore, E.R.B., Rosseló-Móra, R., 2011. Evaluation of matrix-assisted laser desorption ionization time-of-flight whole cell profiles for assessing the cultivable diversity of aerobic and moderately halophilic prokaryotes thriving in solar saltern sediments. Syst. Appl. Microbiol. 34 (1), 69-75. 
Niyompanich, S., Jaresitthikunchai, J., Srisanga, K., Roytrakul, S., Tungpradabkul, S., 2014. Source-identifying biomarker ions between environmental and clinical Burkholderia pseudomallei using whole-cell matrix-assisted laser desorption/ionization time-of-flight mass spectrometry (MALDI-TOF MS). PLoS One 9: e99160. doi: 10.1371/journal.pone.0099160.

Okafor, N (2011): Environmental microbiology of aquatic and waste systems. Springer Dordrecht Heidelberg London New York, doi: 10.1007/978-94-007-1460-1, 303 pp.

Opota, O., Croxatto, A., Prod'hom, G., Greub, G., 2015. Blood culture-based diagnosis of bacteraemia: State of the art. Clin. Microbiol. Infect. 21 (4), 313-322.

Risch, M., Radjenovic, D., Nam Han, J., Wydler, M., Nydegger, U., Risch, L., 2010. Comparison of MALDI TOF with conventional identification of clinically relevant bacteria. Swiss. Med. Wkly. 140: w13095. doi: 10.4414/smw.2010.13095.

Ruelle, V., El Moualij, B., Zorzi, W., Ledent, P., De Pauw, E., 2004. Rapid identification of environmental bacterial strains by matrix-assisted laser desorption ionization-time of flight mass spectrometry. Rapid Commun. Mass Spectrom. 18 (18), 2013-2019.

Saffert, R.T., Cunningham, S.A., Ihde, S.M., Monson Jobe, K.E., Mandrekar, J., Patel, R., 2011. Comparison of Bruker Biotyper matrix-assisted laser desorption ionization-time of flight mass spectrometer to BD Phoenix automated microbiology system for identification of Gram-negative bacilli. J. Clin. Microbiol. 49 (3), 887-892.

Sala-Comorera, L., Vilaró, C., Galofré, B., Blanch, A.R., Garcia-Aljaro, C., 2016. Use of matrixassisted laser desorption/ionization-time of flight (MALDI-TOF) mass spectrometry for bacterial monitoring in routine analysis at a drinking water treatment plant. Int. J. Hyg. Environ. Health, doi: 10.1016/j.ijheh.2016.01.001.

Sandrin, T.R., Goldstein, J.E., Schumaker, S., 2013. MALDI-TOF MS profiling of bacteria at the strain level: A review. Mass Spectrom. Rev. 32 (3), 188-217.

Sauer, S., Kliem, M., 2010. Mass spectrometry tools for the classification and identification of bacteria. Nat. Rev. Microbiol. 8 (1), 74-82.

Schirmeister, F., Wieczorek, A., Dieckmann, R., Taureck, K., Strauch, E., 2014. Evaluation of molecular methods to discriminate the closely related species Vibrio fluvialis and Vibrio furnissii. Int. J. Med. Microbiol. 304 (7), 851-857.

Schloss P.D., Handelsman, J. 2004. Status of the microbial census. Microbiol. Mol. Biol. Rev. 68 (4), 686-691.

Schumann, P., Maier, T., 2014. MALDI-TOF mass spectrometry applied to classification and identification of bacteria. Methods in Microbiol. 41, 275-306. 
Seng, P., Drancourt, M., Gouriet, F., La Scola, B., Fournier, P.-E., Rolain, J.M., Raoult, D., 2009. Ongoing revolution in bacteriology: Routine identification of bacteria by matrix-assisted laser desorption ionization time-of-flight mass spectrometry. Clin. Infect. Dis. 49 (4), 543-551.

Seng, P., Rolain, J.M., Fournier, P.-E, La Scola, B., Drancourt, M., Raoult, D. (2010) MALDITOF-mass spectrometry application in clinical microbiology. Future Microbiol., 5 (11), 17331754.

Siegrist, T.J., Anderson, P.D., Huen, W.H., Kleinheinz, G.T., McDermott, C.M., Sandrin, T.R., 2007. Discrimination and characterization of environmental strains of Escherichia coli by matrix-assisted laser desorption/ionization time-of-flight mass spectrometry (MALDI-TOF MS). J. Microbiol. Methods 68 (3), 554-562.

Sousa, C., Botelho, J., Grosso, F., Silva, L., Lopes, J., Peixe, L., 2015. Unsuitability of MALDITOF MS to discriminate Acinetobacter baumanii clones under routine experimental conditions. Front Microbiol. 6: 481. doi: 10.3389/fmicb.2015.00481.

Sparbier, K., Lange, C., Jung, J., Wieser, A., Schubert, S., Kostrzewa, M., 2013. MALDI Biotyper-based rapid resistance detection by stable-isotope labeling. J. Clin. Microbiol. 51 (11), 3741-3748.

Spitaels, F., Wieme, A.D., Vandamme, P., 2016. MALDI-TOF MS as a novel tool for dereplication and characterization of microbiota in bacterial diversity studies. In: Applications of Mass Spectrometry in Microbiology, P. Demirev, T.R. Sandrin (eds.), doi: 10.1007/978-3-31926070-9_9.

Strupat, K., Karas, M., Hillenkamp, F., 1991.: 2,5-dihydroxybenzoic acid: a new matrix for laser desorption ionisation MS. Int. J. Mass Spectrom. Ion Proc. 111, 89-102.

Taučer-Kapteijn, M., Medema, G., Hoogenboezem, W., 2013. Comparison between Rapid ID 32 Strep system, matrix assisted laser desorption ionization-time of flight mass spectrometry and 16S rRNA gene sequence analysis for the species identification of Enterococcus spp. isolated from water. Water Sci. Tech-W. Sup. 13 (5), 1383-1389.

Telesmanich, N.R., Chăka, S.O., Vodianitskaia, Slu, Chemisova, O.S., Chă̌ka, I.A., 2014. The application of mass spectrometry technique MALDI-TOF for inter-specific differentiation of closely related Vibrio. Klin. Lab. Diagn. 59 (8), 27-28. (abstract in English)

Thevenon, F., Regier, N., Benagli, C., Tonolla, M., Adatte, T., Wildi, W., Poté, J., 2012. Characterization of fecal indicator bacteria in sediments cores from the largest freshwater lake of Western Europe (Lake Geneva, Switzerland). Ecotoxicol. Environ. Saf. 78, 50-56.

Topić Popović, N., Čož-Rakovac, R., Strunjak-Perović, I., 2007. Commercial phenotypic tests (API 20E) in diagnosis of fish bacteria: a review. Vet. Med.-Czech 52, 49-53. 
Topić Popović, N., Sauerborn Klobučar, R., Maguire, I., Strunjak-Perović, I., Kazazić, S., Barišić, J., Jadan, M., Klobučar, G., Čož-Rakovac, R., 2014. High-throughput discrimination of bacteria isolated from Astacus astacus and A. leptodactylus. Knowl. Managt. Aquatic Ecosyst. 413: 04. doi: 10.1051/kmae/2014005.

Topić Popović, N., Kazazić, S.P., Strunjak-Perović, I., Barišić, J., Sauerborn Klobučar, R., Kepec, S., Čož-Rakovac, R., 2015. Detection and diversity of aeromonads from treated wastewater and fish inhabiting effluent and downstream waters. Ecotoxicol. Environ. Saf. 120, 235-242.

van Veen, S.Q., Claas, E.C.J., Kuijper, E.J., 2010. High-throughput identification of bacteria and yeast by matrix-assisted laser desorption ionization-time of flight mass spectrometry in conventional medical microbiology laboratories. J. Clin. Microbiol. 48 (3), 900-907.

Vávrová, A., Balážová, T., Sedláček, I., Tvrzová, L., Šedo, O., 2015. Evaluation of the MALDITOF MS profiling for identification of newly described Aeromonas spp. Folia Microbiol. 60 (5), 375-383.

Viver T., Cifuentes A., Díaz S., Rodríguez-Valdecantos, G., González, B., Antón, J., RossellóMora, R., 2015. Diversity of extremely halophilic cultivable prokaryotes in Mediterranean, Atlantic and Pacific solar salterns: Evidence that unexplored sites constitute sources of cultivable novelty. Syst. Appl. Microbiol., doi: 10.1016/j.syapm.2015.02.002.

Weir, M., Rajić, A., Dutil, L., Cernicchiaro, N., Uhland, F.C., Mercier, B., Tuševljak, N., 2012. Zoonotic bacteria, antimicrobial use and antimicrobial resistance in ornamental fish: A systematic review of the existing research and survey of aquaculture-allied professionals. Epidemiol. Infect. 140 (2), 192-206.

Wieme, A.D., Spitaels, F., Aerts, M., De Bruyne, K., Van Landschoot, A., Vandamme, P., 2014. Identification of beer-spoilage bacteria using matrix-assisted laser desorption/ionization-time of flight mass spectrometry. Int. J. Food Microbiol. 185, 41-50.

Woo, P.T.K., Bruno, D.W., 2011. Fish diseases and disorders. Volume 3: Viral, bacterial and fungal infections. 2nd edition, CAB International, Oxfordshire

Xiao, D., Zhang, C., Zhang, H., Li, X., Jiang, X., Zhang, J., 2015. A novel approach for differentiating pathogenic and non-pathogenic Leptospira based on molecular fingerprinting. J. Proteomics 119, 1-9.

Xie, H.-X., Lu, J.-F., Zhou, Y., Yi, J., Yu, X.-J., Leung, K.Y., Nie, P., 2015. Identification and functional characterization of the novel Edwardsiella tarda effector EseJ. Infect. Immun. 83 (4), 1650-1660. 
Zangenah, S., Özenci, V., Boräng, S., Bergman, P., 2012. Identification of blood and wound isolates of $C$. canimorsus and C. cynodegmi using VITEK 2 and MALDI-TOF. Eur. J. Clin. Microbiol. Infect. Dis. 31, 2631-2637.

Zhang, L., Vranckx, K., Janssens, K., Sandrin, T.R., 2015. Use of MALDI-TOF mass spectrometry and a custom database to characterize bacteria indigenous to a unique cave environment (Kartchner Caverns, AZ, USA). J. Vis. Exp. 95: e52064. doi: 10.3791/52064.

Zhu, S., Ratering, S., Schnell, S., Wacker, R., 2011. Matrix-assisted laser desorption and ionization-time-of-flight mass spectrometry, 16S rRna gene sequencing, and API 32E for identification of Cronobacter spp.: a comparative study. J. Food Prot. 74 (12), 2182-2187. 
Table 1. Advantages and shortcomings of selected methods used for identification of environmental bacteria. Adapted from Buller (2004) and Okafor (2011).

\begin{tabular}{|c|c|c|}
\hline Method & Advantages & Shortcomings \\
\hline $\begin{array}{l}\text { Biochemical } \\
\text { identification kits (API } \\
\text { systems, Vitek) }\end{array}$ & $\begin{array}{l}\text { Easy to perform } \\
\text { Requires limited training }\end{array}$ & $\begin{array}{l}\text { Frequent misidentifications } \\
\text { Limited profile index } \\
\text { Requires cultivation of target organism } \\
\text { and additional tests }\end{array}$ \\
\hline $\begin{array}{l}\text { Random amplification } \\
\text { of polymorphic DNA } \\
\text { (RAPD) } \\
\text { Amplified fragment } \\
\text { length polymorphism } \\
\text { (AFLP-PCR) }\end{array}$ & $\begin{array}{l}\text { Rapid, easy to perform } \\
\text { May be used to differentiate } \\
\text { host source } \\
\text { Highly reproducible } \\
\text { May be used to differentiate } \\
\text { host source }\end{array}$ & $\begin{array}{l}\text { Requires cultivation of target organism } \\
\text { Libraries may be geographically and } \\
\text { temporally specific } \\
\text { Requires specialized training } \\
\text { Requires cultivation of target organism } \\
\text { Requires reference library } \\
\text { Libraries may be geographically and } \\
\text { temporally specific } \\
\text { Method varies according to different } \\
\text { studies }\end{array}$ \\
\hline $\begin{array}{l}\text { Pulsed-field gel } \\
\text { electrophoresis } \\
(\mathrm{PFGE})\end{array}$ & $\begin{array}{l}\text { Highly reproducible } \\
\text { May be used to differentiate } \\
\text { host source }\end{array}$ & $\begin{array}{l}\text { Labor intensive, requires specialized } \\
\text { training } \\
\text { Requires cultivation of target organism } \\
\text { Requires reference library } \\
\text { Libraries may be geographically and } \\
\text { temporally specific }\end{array}$ \\
\hline Ribotyping & $\begin{array}{l}\text { Highly reproducible } \\
\text { Can be automated } \\
\text { May be used to differentiate } \\
\text { host source }\end{array}$ & $\begin{array}{l}\text { Labor intensive, requires specialized } \\
\text { training } \\
\text { Requires cultivation of target organism } \\
\text { Requires reference library } \\
\text { Libraries may be geographically and } \\
\text { temporally specific }\end{array}$ \\
\hline Gene-specific PCR & $\begin{array}{l}\text { Can be adapted to quantify } \\
\text { gene copy number } \\
\text { Virulence genes may be } \\
\text { targeted } \\
\text { Does not require reference } \\
\text { library }\end{array}$ & $\begin{array}{l}\text { Requires enrichment of target organism } \\
\text { Sufficient quantity of target genes may } \\
\text { not be available }\end{array}$ \\
\hline Host-specific PCR & $\begin{array}{l}\text { Rapid, easy to perform } \\
\text { Does not require cultivation } \\
\text { of target organism }\end{array}$ & Limited availability of primers \\
\hline Real-time PCR & $\begin{array}{l}\text { Rapid and reproducible } \\
\text { In use for the microbial risk } \\
\text { assessment of water quality }\end{array}$ & $\begin{array}{l}\text { Requires high technical skill and } \\
\text { support } \\
\text { Requires costly reagents } \\
\text { Not recommended for multiplex assays }\end{array}$ \\
\hline $\begin{array}{l}\text { 16S ribosomal RNA } \\
\text { sequencing }\end{array}$ & $\begin{array}{l}\text { Rapid tool } \\
\text { Best when used jointly with }\end{array}$ & $\begin{array}{l}\text { Requires specialized training } \\
\text { Less accurate at the species level }\end{array}$ \\
\hline
\end{tabular}




\begin{tabular}{lll}
\hline & biochemical tests & $\begin{array}{l}\text { Not all primers bind to the DNA of the } \\
\text { targeted organism }\end{array}$ \\
$\begin{array}{ll}\text { Fluorescence in situ } \\
\text { hybridization (FISH) }\end{array}$ & $\begin{array}{l}\text { Rapid, easy to perform } \\
\text { Used increasingly for } \\
\text { identification of bacteria } \\
\text { from clinical samples }\end{array}$ & $\begin{array}{l}\text { Requires cultivation of target organism } \\
\text { Requires development of specific FISH } \\
\text { assays for targeted organism }\end{array}$ \\
& Limited availability of primers \\
\hline
\end{tabular}


Table 2. Most frequently occurring bacterial pathogens of aquatic species. Bacteria are listed with respective names and symptoms of diseases, the tissues from which they can be retrieved, and aquatic animals where the organism has been reported. Adapted from Austin and Austin (1999), Buller (2004), Woo and Bruno (2011).

\begin{tabular}{|c|c|c|c|c|}
\hline $\begin{array}{l}\text { Pathogen/Identifiable } \\
\text { from the MALDI-TOF } \\
\text { MS databases }\end{array}$ & Disease & Signs of disease & $\begin{array}{l}\text { Isolation } \\
\text { tissue/host }\end{array}$ & Distribution \\
\hline $\begin{array}{l}\text { Aeromonas caviae } \\
\text { (HG4)/yes }\end{array}$ & $\begin{array}{l}\text { Septicemia, } \\
\text { gastroenteritis, } \\
\text { mortalities }\end{array}$ & $\begin{array}{l}\text { Dermal ulcers, } \\
\text { hepatopancreatic } \\
\text { infections }\end{array}$ & $\begin{array}{l}\text { Freshwater } \\
\text { and } \\
\text { ornamental } \\
\text { fish, Atlantic } \\
\text { salmon, giant } \\
\text { freshwater } \\
\text { prawn, turbot } \\
\text { larvae, } \\
\text { crayfish; } \\
\text { Humans }\end{array}$ & $\begin{array}{l}\text { Ubiquitous in } \\
\text { the } \\
\text { environment, } \\
\text { worldwide }\end{array}$ \\
\hline $\begin{array}{l}\text { Aeromonas } \\
\text { hydrophila ssp. } \\
\text { hydrophila (HG1)/yes }\end{array}$ & $\begin{array}{l}\text { Hemorrhagic } \\
\text { septicemia, } \\
\text { peritonitis, redsore } \\
\text { disease, fin rot, } \\
\text { red-fin disease, } \\
\text { black disease, } \\
\text { mortalities }\end{array}$ & $\begin{array}{l}\text { Erosive or } \\
\text { ulcerative dermal } \\
\text { lesions, } \\
\text { hemorrhage on } \\
\text { fins and trunk, } \\
\text { swelling of anus, } \\
\text { erythema (fish); } \\
\text { Hemorrhage on } \\
\text { legs (frogs); } \\
\text { Black nodules on } \\
\text { thoracic } \\
\text { appendages } \\
\text { (crayfish) }\end{array}$ & $\begin{array}{l}\text { Freshwater } \\
\text { and } \\
\text { ornamental } \\
\text { fish, ayu, } \\
\text { channel } \\
\text { catfish, tilapia, } \\
\text { trout, turtles, } \\
\text { crayfish, } \\
\text { reptiles, grey } \\
\text { seal, } \\
\text { occasionally } \\
\text { marine fish } \\
\text { and scallops, } \\
\text { frogs, shrimps; } \\
\text { Humans }\end{array}$ & $\begin{array}{l}\text { Ubiquitous in } \\
\text { the } \\
\text { environment, } \\
\text { worldwide }\end{array}$ \\
\hline $\begin{array}{l}\text { Aeromonas } \\
\text { salmonicida ssp. } \\
\text { salmonicida } \\
\text { (HG3)/yes }\end{array}$ & $\begin{array}{l}\text { Furunculosis of } \\
\text { salmonid fish, } \\
\text { goldfish ulcer } \\
\text { disease }\end{array}$ & $\begin{array}{l}\text { Dermal ulcers } \\
\text { with typical } \\
\text { furuncles; } \\
\text { organisms } \\
\text { penetrate to } \\
\text { underlying } \\
\text { tissues, kidney, } \\
\text { spleen, intestine }\end{array}$ & $\begin{array}{l}\text { Many species } \\
\text { of freshwater } \\
\text { and marine } \\
\text { fish, frogs, } \\
\text { crayfish }\end{array}$ & $\begin{array}{l}\text { North } \\
\text { America, } \\
\text { Europe } \\
\text { (highly } \\
\text { virulent } \\
\text { strain) }\end{array}$ \\
\hline $\begin{array}{l}\text { Aeromonas } \\
\text { salmonicida ssp. } \\
\text { achromogenes/yes }\end{array}$ & $\begin{array}{l}\text { Variety of } \\
\text { pathologies, carp } \\
\text { erythrodermatitis, } \\
\text { goldfish ulcer }\end{array}$ & $\begin{array}{l}\text { Large open skin } \\
\text { lesions } \\
\text { surrounded by } \\
\text { areas of }\end{array}$ & $\begin{array}{l}\text { Organisms } \\
\text { from } \\
\text { freshwater, } \\
\text { brackish water }\end{array}$ & Worldwide \\
\hline
\end{tabular}




\begin{tabular}{|c|c|c|c|c|}
\hline & $\begin{array}{l}\text { disease, ulcer } \\
\text { disease of flounder, } \\
\text { mortalities }\end{array}$ & $\begin{array}{l}\text { descalation with } \\
\text { hemorrhagic } \\
\text { dermis }\end{array}$ & $\begin{array}{l}\text { and marine } \\
\text { environments }\end{array}$ & \\
\hline $\begin{array}{l}\text { Aeromonas veronii } \\
\text { ssp. sobria/yes }\end{array}$ & $\begin{array}{l}\text { Epizootic } \\
\text { ulcerative fish } \\
\text { syndrome, } \\
\text { mortalities }\end{array}$ & $\begin{array}{l}\text { Large ulcers all } \\
\text { over the fish } \\
\text { body, infectious } \\
\text { dropsy, ascites }\end{array}$ & $\begin{array}{l}\text { Freshwater } \\
\text { and marine } \\
\text { fish; } \\
\text { Humans (the } \\
\text { most } \\
\text { pathogenic of } \\
\text { all } \\
\text { aeromonads) }\end{array}$ & Worldwide \\
\hline $\begin{array}{l}\text { Carnobacterium } \\
\text { (Lactobacillus) } \\
\text { piscicola/yes }\end{array}$ & $\begin{array}{l}\text { Pseudokidney } \\
\text { disease, } \\
\text { lactobacillosis, } \\
\text { post-stripping } \\
\text { peritonitis }\end{array}$ & $\begin{array}{l}\text { Visceral } \\
\text { granulomas, } \\
\text { epicarditis, } \\
\text { peritonitis, } \\
\text { ascites, blood or } \\
\text { blisters under the } \\
\text { skin }\end{array}$ & $\begin{array}{l}\text { Salmonid fish, } \\
\text { catfish }\end{array}$ & $\begin{array}{l}\text { North } \\
\text { America, } \\
\text { Europe, } \\
\text { Australia }\end{array}$ \\
\hline $\begin{array}{l}\text { Citrobacter } \\
\text { freundii/yes }\end{array}$ & Systemic infections & $\begin{array}{l}\text { Hemorrhagic } \\
\text { spots on the skin, } \\
\text { eye and fins. }\end{array}$ & $\begin{array}{l}\text { Angelfish, } \\
\text { trout, carp, } \\
\text { crayfish, } \\
\text { bullfrogs }\end{array}$ & $\begin{array}{l}\text { In water, } \\
\text { sewage, soil, } \\
\text { worldwide }\end{array}$ \\
\hline $\begin{array}{l}\text { Edwardsiella } \\
\text { ictaluri/yes }\end{array}$ & $\begin{array}{l}\text { Enteric septicemia } \\
\text { of catfish, chronic } \\
\text { encephalitis }\end{array}$ & $\begin{array}{l}\text { Petechial } \\
\text { hemorrhage } \\
\text { under jaw and } \\
\text { belly; head, gill } \\
\text { and kidney } \\
\text { lesions, } \\
\text { exophthalmia, } \\
\text { gastroenteritis }\end{array}$ & $\begin{array}{l}\text { Catfish, } \\
\text { freshwater } \\
\text { ornamental } \\
\text { fish, bass, } \\
\text { eels, crayfish, } \\
\text { frogs, turtles }\end{array}$ & $\begin{array}{l}\text { In water, } \\
\text { sediment, } \\
\text { organically } \\
\text { polluted } \\
\text { waters, Asia } \\
\text { and North } \\
\text { America }\end{array}$ \\
\hline $\begin{array}{l}\text { Edwardsiella } \\
\text { tarda/yes }\end{array}$ & $\begin{array}{l}\text { Edwardsiellosis, } \\
\text { redpest, } \\
\text { emphysematous } \\
\text { putrefactive } \\
\text { disease of catfish, } \\
\text { fish gangrene }\end{array}$ & $\begin{array}{l}\text { Septicemia, } \\
\text { ulcerative } \\
\text { dermatitis, } \\
\text { intestinal } \\
\text { infection, lesions } \\
\text { in the muscle, } \\
\text { kidney, liver }\end{array}$ & $\begin{array}{l}\text { Many aquatic } \\
\text { animals: fish, } \\
\text { frogs, } \\
\text { crayfish, } \\
\text { amphibians, } \\
\text { reptiles, } \\
\text { mammals, } \\
\text { turtles; } \\
\text { Humans }\end{array}$ & $\begin{array}{l}\text { Ubiquitous in } \\
\text { the } \\
\text { environment } \\
\text { worldwide }\end{array}$ \\
\hline $\begin{array}{l}\text { Flavobacterium } \\
\text { columnare } \\
\text { (previously } \\
\text { Cytophaga } \\
\text { columnaris, } \\
\text { Flexibacter } \\
\text { columnaris)/yes }\end{array}$ & $\begin{array}{l}\text { Columnaris } \\
\text { disease, saddleback } \\
\text { disease }\end{array}$ & $\begin{array}{l}\text { Lesions on gills, } \\
\text { ulcers and } \\
\text { necrosis on body } \\
\text { surface }\end{array}$ & $\begin{array}{l}\text { Freshwater } \\
\text { fish, crayfish }\end{array}$ & Worldwide \\
\hline
\end{tabular}




\begin{tabular}{|c|c|c|c|c|}
\hline Hafnia alvei/yes & $\begin{array}{l}\text { Hemorrhagic } \\
\text { septicemia, } \\
\text { mortalities }\end{array}$ & $\begin{array}{l}\text { Swollen } \\
\text { abdomen, } \\
\text { furuncle-like } \\
\text { lesions in kidney, } \\
\text { darkening of skin }\end{array}$ & $\begin{array}{l}\text { Salmonids, } \\
\text { frogs, } \\
\text { crayfish; } \\
\text { Humans }\end{array}$ & $\begin{array}{l}\text { Soil, sewage, } \\
\text { water, } \\
\text { Europe, } \\
\text { Japan }\end{array}$ \\
\hline $\begin{array}{l}\text { Listonella } \\
\text { anguillarum } \\
\text { serotypes 01,02 } \\
\text { (previously Vibrio } \\
\text { anguillarum)/yes }\end{array}$ & $\begin{array}{l}\text { Vibriosis, } \\
\text { ulcerative disease, } \\
\text { necrosis }\end{array}$ & $\begin{array}{l}\text { Red spots on } \\
\text { body surface, } \\
\text { ulcerative skin } \\
\text { lesions }\end{array}$ & $\begin{array}{l}\text { Freshwater } \\
\text { and marine } \\
\text { fish, crayfish, } \\
\text { molluscs }\end{array}$ & Worldwide \\
\hline $\begin{array}{l}\text { Mycobacterium } \\
\text { spp./yes }\end{array}$ & Mycobacteriosis & $\begin{array}{l}\text { Lesions on skin } \\
\text { and kidneys, } \\
\text { nodules in tissues }\end{array}$ & $\begin{array}{l}\text { Freshwater } \\
\text { and marine } \\
\text { fish, crayfish, } \\
\text { mollusks, } \\
\text { frogs, reptiles, } \\
\text { turtles, } \\
\text { crocodiles: } \\
\text { Humans }\end{array}$ & Worldwide \\
\hline $\begin{array}{l}\text { Pantoea } \\
\text { (Enterobacter) } \\
\text { agglomerans/yes }\end{array}$ & $\begin{array}{l}\text { Hemorrhagic } \\
\text { septicemia }\end{array}$ & $\begin{array}{l}\text { Hemorrhages in } \\
\text { eyes, dorsal } \\
\text { musculature }\end{array}$ & $\begin{array}{l}\text { Freshwater } \\
\text { and marine } \\
\text { fish; } \\
\text { Humans }\end{array}$ & Worldwide \\
\hline $\begin{array}{l}\text { Photobacterium } \\
\text { damselae ssp. } \\
\text { damselae (previously } \\
\text { Vibrio damselae, EF- } \\
\text { 5)/yes }\end{array}$ & $\begin{array}{l}\text { Vibriosis, } \\
\text { granulomatous } \\
\text { ulcerative } \\
\text { dermatitis }\end{array}$ & $\begin{array}{l}\text { Skin ulcers, soft } \\
\text { tissue infections }\end{array}$ & $\begin{array}{l}\text { Freshwater } \\
\text { and marine } \\
\text { fish, mollusks, } \\
\text { crayfish, } \\
\text { turtles; } \\
\text { Humans }\end{array}$ & Worldwide \\
\hline $\begin{array}{l}\text { Photobacterium } \\
\text { damselae ssp. } \\
\text { piscicida (previously } \\
\text { Pasteurella piscicida, } \\
\text { Flavobacterium } \\
\text { piscicida, } \\
\text { Pseudomonas } \\
\text { piscicida)/yes }\end{array}$ & $\begin{array}{l}\text { Pasteurellosis, fish } \\
\text { pseudotuberculosis }\end{array}$ & $\begin{array}{l}\text { White nodules in } \\
\text { internal organs }\end{array}$ & $\begin{array}{l}\text { Freshwater } \\
\text { and marine } \\
\text { fish }\end{array}$ & $\begin{array}{l}\text { Worldwide, } \\
\text { not in } \\
\text { Australia }\end{array}$ \\
\hline $\begin{array}{l}\text { Renibacterium } \\
\text { salmoninarum/yes }\end{array}$ & $\begin{array}{l}\text { Bacterial kidney } \\
\text { disease }\end{array}$ & $\begin{array}{l}\text { Exophthalmia, } \\
\text { blisters on flank, } \\
\text { ulcers, abscesses, } \\
\text { lesions over } \\
\text { organs, necrotic } \\
\text { abscesses in } \\
\text { kidney }\end{array}$ & Salmonids & $\begin{array}{l}\text { Worldwide, } \\
\text { not in } \\
\text { Australia }\end{array}$ \\
\hline $\begin{array}{l}\text { Tenacibaculum } \\
\text { maritimum } \\
\text { (previously }\end{array}$ & $\begin{array}{l}\text { Columnaris } \\
\text { disease, erosive } \\
\text { skin disease, black }\end{array}$ & $\begin{array}{l}\text { Eroded mouth } \\
\text { and fins, } \\
\text { ulcerated skin }\end{array}$ & Marine fish & $\begin{array}{l}\text { North } \\
\text { America, } \\
\text { Europe, Asia }\end{array}$ \\
\hline
\end{tabular}




\begin{tabular}{|c|c|c|c|c|}
\hline $\begin{array}{l}\text { Cytophaga marina } \\
\text { and Flexibacter } \\
\text { maritimus)/yes }\end{array}$ & $\begin{array}{l}\text { patch necrosis, } \\
\text { mouth rot }\end{array}$ & lesions & & \\
\hline Vibrio fluvialis/yes & Mortalities & $\begin{array}{l}\text { Lesions in } \\
\text { internal organs }\end{array}$ & $\begin{array}{l}\text { Mostly fish } \\
\text { from brackish } \\
\text { waters, marine } \\
\text { mollusks, } \\
\text { crustacea; } \\
\text { Humans }\end{array}$ & Worldwide \\
\hline Vibrio harveyi/yes & $\begin{array}{l}\text { Vibriosis, } \\
\text { mortalities in } \\
\text { sharks and abalone }\end{array}$ & $\begin{array}{l}\text { Necrotic } \\
\text { degenerations, } \\
\text { vacuolations in } \\
\text { lesions, extended } \\
\text { abdomen, red } \\
\text { anus }\end{array}$ & $\begin{array}{l}\text { Fish, } \\
\text { mollusks, } \\
\text { penaeid } \\
\text { prawns and } \\
\text { shrimps, } \\
\text { octopus; } \\
\text { Humans }\end{array}$ & Worldwide \\
\hline $\begin{array}{l}\text { Vibrio } \\
\text { parahaemolyticus/yes }\end{array}$ & $\begin{array}{l}\text { Withering } \\
\text { syndrome, } \\
\text { septicemia, } \\
\text { mortalities }\end{array}$ & $\begin{array}{l}\text { External } \\
\text { hemorrhages, tail } \\
\text { rot }\end{array}$ & $\begin{array}{l}\text { Fish, } \\
\text { crustaceans, } \\
\text { abalone; } \\
\text { Humans }\end{array}$ & $\begin{array}{l}\text { Mostly Asia, } \\
\text { spreading } \\
\text { worldwide }\end{array}$ \\
\hline $\begin{array}{l}\text { Vibrio vulnificus } \\
\text { biotype I/yes }\end{array}$ & $\begin{array}{l}\text { Vibriosis, } \\
\text { hemorrhagic } \\
\text { septicemia, } \\
\text { ulcerative disease }\end{array}$ & $\begin{array}{l}\text { Ulcerous lesions, } \\
\text { intestinal } \\
\text { degenerations, } \\
\text { necrosis }\end{array}$ & $\begin{array}{l}\text { Marine and } \\
\text { brackish fish, } \\
\text { mollusks, } \\
\text { crayfish, } \\
\text { plankton; } \\
\text { Humans }\end{array}$ & Worldwide \\
\hline Yersinia ruckeri/yes & $\begin{array}{l}\text { Enteric redmouth } \\
\text { disease, yersiniosis }\end{array}$ & $\begin{array}{l}\text { Reddening of } \\
\text { throat and } \\
\text { mouth, } \\
\text { hemorrhages on } \\
\text { gills, eyes, } \\
\text { muscles }\end{array}$ & $\begin{array}{l}\text { Freshwater } \\
\text { and marine } \\
\text { fish }\end{array}$ & Worldwide \\
\hline
\end{tabular}


Figure 1. Exemplary MALDI-TOF MS profiles of bacteria isolated from different freshwater crayfish tissues. Numbers refer to identification scores obtained with the Bruker MALDIbiotyper. Scores of 2.0 or higher are considered as highly probable species identification. Reprinted from Topić Popović et al., 2014. 